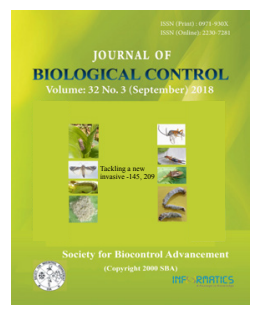

Research Article

\title{
A study on five sampling methods of parasitic hymenopterans in rice ecosystem
}

\author{
J. ALFRED DANIEL ${ }^{1^{*}}$, K. RAMARAJU ${ }^{2}$, S. MOHAN KUMAR ${ }^{3}$, P. JEYAPRAKASH ${ }^{4}$ and N. CHITRA ${ }^{1}$ \\ ${ }^{1}$ Department of Agricultural Entomology, Tamil Nadu Agricultural University, Coimbatore -641003, Tamil Nadu, India \\ ${ }^{2}$ Director of Research, Tamil Nadu Agricultural University, Coimbatore - 641003, Tamil Nadu, India \\ ${ }^{3}$ Department of Plant Biotechnology, Tamil Nadu Agricultural University, Coimbatore - 641003, Tamil Nadu, India \\ ${ }^{4}$ Department of Rice, Tamil Nadu Agricultural University, Coimbatore - 641003, Tamil Nadu, India \\ ${ }^{*}$ Corresponding author Email: danieljalfred@gmail.com
}

\begin{abstract}
For insect diversity studies to be of value, the sampling methods employed must produce samples representative of the community or taxon selected for the investigation. However, as yet, few evaluations on the variability and effectiveness of sampling methods have been undertaken. The survey was carried out in the rice fields during 2015-16 in Paddy Breeding Station, Tamil Nadu Agricultural University, Coimbatore. From this study a total of 1,019 parasitoid individuals were collected. Among six different collection methods employed for sampling hymenopteran parasitoids in rice ecosystem, the yellow pan trap at ground level was found to be the most effective method in trapping the parasitoids $(27.2 \pm 2.56$ parasitoids per day) followed by sweep net method (12.1 \pm 1.03 parasitoids per day). The next best sampling method is yellow pan trap erected at canopy level which recorded a mean of $9.2 \pm 2.26$ parasitoids per day. The other three traps viz., malaise trap, suction trap and light trap were found to collect less number $(<1.5)$ of parasitoids per day.
\end{abstract}

KEY WORDS: Efficiency, parasitoids, rice, sampling, traps

(Article chronicle: Received: 26-04-2018; Revised: 23-08-2018; Accepted: 15-09-2018)

\section{INTRODUCTION}

Rice fields harbour a rich and varied fauna than any other agricultural crop (Heckman, 1979; Fritz et al., 2011). The fauna is dominated by micro, meso and macro arthropods inhabiting the soil, water and vegetation sub-habitats of the rice fields. The different communities of terrestrial arthropods in the rice field include pests, their natural enemies (predators and parasitoids) and other neutral insects that inhabit or visit the vegetation as tourists (Heong et al., 1991). Recently, biodiversity in agricultural land has received growing attention because it plays a significant role in agro-ecosystem function by keeping pest populations under check (Jervis et al., 2007). Most parasitic hymenopterans are keystone species and the removal of keystone species will result in cascade effect in the ecosystem (La-Salle and Gauld, 1993). Despite their importance, our understanding of their taxonomy and diversity is clearly wanting. Therefore, more emphasis should be given for the identification, conservation and use of parasitic Hymenoptera in insect pest management programmes. This will render high economic returns to the farmers besides sustainable ecofriendly pest management. For insect diversity studies to be of value, the sampling methods employed must produce samples representative of the community or taxon selected for the investigation. However, as yet, few evaluations on the variability and effectiveness of sampling methods have been undertaken. Literature concerning methods of sampling Hymenoptera are relatively limited (Noyes, 1989). It is a well known fact that each group of insects requires its own specialized technique and apparatus for trapping. If the wrong technique is used, the catch/collection may be very poor and the results must be misleading, apart from tiresome and time taking efforts of the workers. Hence, trapping efficiency of different traps has to be an integral part of any diversity study. In this context, the present study was undertaken.

\section{MATERIALS AND METHODS}

\section{Site of collection}

The survey was carried out in the rice fields during 2015-16 in the western agro climatic zone of Tamil Nadu State (District representation: Coimbatore at, Paddy Breeding Station, Coimbatore, $\left.427 \mathrm{~m}, 10^{\circ} 59^{\prime} 43.24^{\prime \prime} \mathrm{N} 76^{\circ} 54^{\prime} 59.22^{\prime \prime} \mathrm{E}\right)$. Collections were made for 20 consecutive days. The time of sampling was during August $16^{\text {th }}$ to September $04^{\text {th }}$ of 2015. The crop was in vegetative phase during the survey.

\section{Methods of collection}

A total of six different collecting devices viz., sweep net, yellow pan trap kept at ground level, yellow pan trap erected at canopy levels, Malaise trap, suction trap and light trap were 
employed for the collection of parasitoids from rice ecosystems of Tamil Nadu. All the six collecting devices were employed continuously for 20 days.

\section{Sweep net}

The net employed for collecting was essentially similar to an ordinary insect net with $673 \mathrm{~mm}$ mouth diameter and a $1076 \mathrm{~mm}$ long aluminum handle. The net bag was made up of thin cotton cloth. Sweeping of vegetation was as random as possible from ground level to the height of the crop. Sweeping was done in early morning and late evening hours for about half an hour per day which involved 30 sweeps. One to and fro motion of the sweep net was considered as one sweep.

\section{Yellow pan traps kept at ground level}

This trap was based on the principle that many insects are attracted to bright yellow colour. Yellow pan traps are shallow trays of $133 \mathrm{~mm} \times 195 \mathrm{~mm}$ and $48 \mathrm{~mm}$ deep and was of bright yellow in colour. Altogether, twenty yellow pan traps were installed at ground level in each site on the bunds, half- filled with water containing a few drops of commercially available detergent (to break the surface tension) and a pinch of salt (to reduce the rate of evaporation and to prevent rotting of trapped insects). The spacing between traps was standardized as $1.5 \mathrm{~m}$. The traps were set for a period of 24 hours (Example: traps set at $10 \mathrm{AM}$ on one day was serviced at $10 \mathrm{AM}$ on the following day).

\section{Yellow pan traps erected up to canopy level}

Erected yellow pan traps were installed at the crop canopy by means of polyvinyl chloride pipes fitted below, with a screw attachment and were installed in 10 numbers per site in the same fashion as yellow pan trap kept at ground level.

\section{Malaise trap}

This trap makes use of the negatively geotactic and positively phototactic behavior of insects. This is a tent like trap made of fine-mesh $(108 \times 32 \mathrm{mesh} / \mathrm{square}$ inch $)$ terylene gauze with a specially adapted collecting bottle at the top. The bottle has a capacity to hold $500 \mathrm{ml}$. The trap is about 6 feet wide, 3 feet and 6 inches high at one end and 6 feet and 6 inches high at other end. The parasitoids fly into the sides of the trap by chance, crawl up to the roof (negatively geotactic behaviour), where they enter a collecting bottle (situated in a direction of sunlight-positively phototactic behaviour) containing 70 per cent alcohol. This trap was emptied once in 5 days.

\section{Suction trap}

Suction trap is otherwise called as Dietrick vacuum sampler, or D-Vac (Model 1A), which was designed specifically for sampling arthropods in grasslands and agricultural crops.
The insects are drawn down a gauze cone into a collecting tube by a ventilating fan mounted with the blades in a horizontal plane. The suction action was achieved by a diesel operated motor. As the trap is heavy, it is harder to operate more than $15 \mathrm{~min}$. per day. It was operated along the bunds, grassy borders and harvested fields.

\section{Light trap}

A solar operated light trap was utilized so as to document the parasitoid activity during night. The operating voltage of the trap is $6 \mathrm{~V} \mathrm{DC}$, with a solar PV cell of $3 \mathrm{~W} / 6 \mathrm{~V}$, consisting a battery $6 \mathrm{~V}, 4.5 \mathrm{AH}$. This enables the solar light trap to operate continuously for 3 hours per day (i.e., the trap was operated form 7.00 PM to 10 PM each day). This ready made trap is very easy to install and was installed on the bunds. It consists of a collecting vessel, where insects got trapped, which will be emptied the next day morning.

\section{Preservation and identification of the specimens up to family level}

The Parasitoids thus collected were preserved in $70 \%$ ethyl alcohol. The dried specimens were mounted on pointed triangular cards and studied under a Stemi (Zeiss) 2000-C and Photographed under Leica M 205-A stereo zoom microscopes and identified through conventional taxonomic techniques by following standard keys of Narendran (1994), Jonathan (2006), Rajmohana (2006) and Sureshan (2008) and Noyes (2017). In addition, help was also taken from already identified collection of parasitoids at Parasitoid Taxonomy Lab, Annamalai University, Chidambaram. Identified collections are deposited at Insect Biosystematics lab, Department of Agricultural Entomology, Tamil Nadu Agricultural University, Coimbatore.

\section{Statistical analysis}

The statistical test ANOVA was also used to check whether there was any significant difference in the collections from different traps. The data on population number were transformed into $\mathrm{X}+0.5$ square root before statistical analysis. The mean individuals caught from six different traps were analyzed by adopting Randomized Block Design (RBD) to find Least Significant Difference (LSD). Critical Difference (CD) values were calculated at five per cent probability level. All these statistical analyses were done using Microsoft Excel 2016 version and Agres software version 3.01.

\section{RESULTS AND DISCUSSION}

\section{Evaluation of six collection methods for hymenopteran parasitoids in rice ecosystem}

From this study a total of 1,019 parasitoid individuals were collected. Among six different collection methods employed for sampling hymenopteran parasitoids in rice ecosys- 
tem, the yellow pan trap at ground level was found to be the most effective method in trapping the parasitoids ( $27.2 \pm 2.56$ parasitoids per day) followed by sweep net method $(12.1 \pm 1.03$ parasitoids per day). The next best sampling method is yellow pan trap erected at canopy level which recorded a mean of $9.2 \pm 2.26$ parasitoids per day. The other three traps viz., malaise trap, suction trap and light trap were found to collect less number $(<1.5)$ of parasitoids per day (Table 1$)$.

Table 1. Hymenopteran parasitoids collected by different collection methods in rice ecosystem

\begin{tabular}{|l|l|}
\hline Collecting devices & $\begin{array}{l}\text { Mean No. of parasitoids } \\
\text { collected/day }\end{array}$ \\
\hline Sweep net & $12.1 \pm 1.03(3.45)^{\mathrm{b}}$ \\
\hline Yellow pan trap (ground level) & $27.2 \pm 2.56(5.16)^{\mathrm{a}}$ \\
\hline Yellow pan trap (erected) & $9.2 \pm 2.26(2.80)^{\mathrm{c}}$ \\
\hline Malaise trap & $1.25 \pm 0.23(1.26)^{\mathrm{d}}$ \\
\hline Suction trap & $0.7 \pm 0.19(1.03)^{\mathrm{d}}$ \\
\hline Light trap & $0.5 \pm 0.28(0.99)^{\mathrm{d}}$ \\
\hline S.E.D & 0.26 \\
\hline C.D $(\mathrm{p}=0.05)$ & 0.52 \\
\hline
\end{tabular}

Figures in parentheses are square root transformed values.

In a column, means followed by a common letter(s) are not significantly different by LSD $(\mathrm{p}=0.0)$

\section{Efficiency of traps in collecting different super families of parasitic Hymenoptera}

The following super families of parasitic Hymenoptera viz., Apoidea, Chrysidoidea, Vespoidea, Ceraphronoidea, Chalcidoidea, Cynipoidea, Diaprioidea, Evanioidea, Ichneumonoidea, Platygasteroidae and Proctotrupoidea were collected by adopting six different sampling methods. In case of Apoidea, a mean of $0.05 \pm 0.05$ was caught only in sweep net per day and not in any other collecting devices (Table 2). No collecting device was found superior in collecting Chrysidoidea and a mean of $0.20 \pm 0.13$ chyrsidoids per day was caught in sweep netting as well as in light trap. No chrysidoids was caught in suction trap. Sweep net was found to be the best in collecting Vespoidea which recorded a mean collection of $0.20 \pm 0.11$ vespoids per day, which is statistically superior to all other methods of collection. Yellow pan trap at ground level was found to perform well over other methods in trapping ceraphronoids with a mean of $3.60 \pm 0.81$ per day. For collecting chalcidoids, both sweep net and yellow pan trap kept at ground level were found significantly superior and on par with each other with a mean collection of $3.95 \pm 0.66$ and $5.05 \pm 0.88$ chalcidoids, respectively followed by yellow pan trap (erected) ( $1.30 \pm 0.65$ chacidoids per day). Cynipoids were trapped only in yellow pan trap (ground level) with a mean of $0.10 \pm 0.10$ cynipoids per day. In case of Diaprioidea, yellow pan trap

Table 2. Efficiency of traps in collecting parasitic hymenopteran superfamilies

\begin{tabular}{|c|c|c|c|c|c|c|c|c|}
\hline \multirow{2}{*}{ Superfamilies } & \multicolumn{6}{|l|}{ Traps } & \multirow{2}{*}{ S.ED } & \multirow{2}{*}{$\begin{array}{l}\text { CD } \\
(p=0.05)\end{array}$} \\
\hline & Sweep Net & YPT-1 & YPT-2 & Malaise Trap & Suction Trap & Light Trap & & \\
\hline Apoidea & $\begin{array}{l}0.05 \pm 0.05 \\
(0.73)\end{array}$ & $\begin{array}{l}0.00 \pm 0.00 \\
(0.71)\end{array}$ & $\begin{array}{l}0.00 \pm 0.00 \\
(0.71)\end{array}$ & $\begin{array}{l}0.00 \pm 0.00 \\
(0.71)\end{array}$ & $\begin{array}{l}0.00 \pm 0.00 \\
(0.71) \\
\end{array}$ & $\begin{array}{l}0.00 \pm 0.00 \\
(0.71)\end{array}$ & 0.01 & NS \\
\hline Chrysidoidea & $\begin{array}{l}0.20 \pm 0.13 \\
(0.79)\end{array}$ & $\begin{array}{l}0.05 \pm 0.05 \\
(0.73)\end{array}$ & $\begin{array}{l}0.05 \pm 0.05 \\
(0.73)\end{array}$ & $\begin{array}{l}0.15 \pm 0.08 \\
(0.78)\end{array}$ & $\begin{array}{l}0.00 \pm 0.00 \\
(0.71)\end{array}$ & $\begin{array}{l}0.20 \pm 0.20 \\
(0.78)\end{array}$ & 0.06 & NS \\
\hline Vespoidea & $\begin{array}{l}0.20 \pm 0.11 \\
(0.80)^{\mathrm{a}} \\
\end{array}$ & \begin{tabular}{|l|}
$0.00 \pm 0.00$ \\
$(0.71)^{\mathrm{b}}$ \\
\end{tabular} & $\begin{array}{l}0.00 \pm 0.00 \\
(0.71)^{\mathrm{b}}\end{array}$ & $\begin{array}{l}0.00 \pm 0.00 \\
(0.71)^{\mathrm{b}}\end{array}$ & \begin{tabular}{|l|}
$0.00 \pm 0.00$ \\
$(0.71)^{\mathrm{b}}$ \\
\end{tabular} & $\begin{array}{l}0.00 \pm 0.00 \\
(0.71)^{\mathrm{b}}\end{array}$ & 0.03 & 0.06 \\
\hline Ceraphronoidea & $\begin{array}{l}0.20 \pm 0.20 \\
(0.77)^{\mathrm{b}}\end{array}$ & $\begin{array}{l}3.60 \pm 0.81 \\
(1.77)^{a}\end{array}$ & $\begin{array}{l}0.65 \pm 0.35 \\
(0.94)^{\mathrm{b}}\end{array}$ & $\begin{array}{l}0.10 \pm 0.06 \\
(0.75)^{\mathrm{b}}\end{array}$ & $\begin{array}{l}0.25 \pm 0.09 \\
(0.83)^{\mathrm{b}}\end{array}$ & $\begin{array}{l}0.00 \pm 0.00 \\
(0.71)^{\mathrm{b}}\end{array}$ & 0.15 & 0.31 \\
\hline Chalcidoidea & $\begin{array}{l}3.95 \pm 0.66 \\
(1.97)^{\mathrm{a}}\end{array}$ & $\begin{array}{l}5.05 \pm 0.88 \\
(2.19)^{\mathrm{a}}\end{array}$ & $\begin{array}{l}1.30 \pm 0.65 \\
(1.10)^{\mathrm{b}}\end{array}$ & $\begin{array}{l}0.10 \pm 0.10 \\
(0.75)^{\mathrm{bc}}\end{array}$ & $\begin{array}{l}0.35 \pm 0.16 \\
(0.86)^{\mathrm{bc}}\end{array}$ & $\begin{array}{l}0.00 \pm 0.00 \\
(0.70)^{\mathrm{bc}}\end{array}$ & 0.18 & 0.35 \\
\hline Cynipoidea & \begin{tabular}{|l|}
$0.00 \pm 0.00$ \\
$(0.71)$ \\
\end{tabular} & $\begin{array}{l}0.10 \pm 0.10 \\
(0.75) \\
\end{array}$ & $\begin{array}{l}0.00 \pm 0.00 \\
(0.71)\end{array}$ & $\begin{array}{l}0.00 \pm 0.00 \\
(0.71)\end{array}$ & \begin{tabular}{|l|}
$0.00 \pm 0.00$ \\
$(0.71)$ \\
\end{tabular} & $\begin{array}{l}0.00 \pm 0.00 \\
(0.71)\end{array}$ & 0.02 & NS \\
\hline Diaprioidea & $\begin{array}{l}1.30 \pm 0.48 \\
(1.16)^{b}\end{array}$ & $\begin{array}{l}4.85 \pm 1.37 \\
(1.90)^{\mathrm{a}}\end{array}$ & $\begin{array}{l}1.50 \pm 0.59 \\
(1.20)^{\mathrm{b}}\end{array}$ & $\begin{array}{l}0.55 \pm 0.22 \\
(0.94)^{\mathrm{b}}\end{array}$ & $\begin{array}{l}0.10 \pm 0.10 \\
(0.75)^{\mathrm{b}}\end{array}$ & $\begin{array}{l}0.20 \pm 0.20 \\
(0.77)^{\mathrm{b}}\end{array}$ & 0.23 & 0.45 \\
\hline Evanioidea & \begin{tabular}{|l|}
$0.25 \pm 0.20$ \\
$(0.80)$ \\
\end{tabular} & $\begin{array}{l}0.00 \pm 0.00 \\
(0.71) \\
\end{array}$ & $\begin{array}{l}0.00 \pm 0.00 \\
(0.71)\end{array}$ & $\begin{array}{l}0.00 \pm 0.00 \\
(0.71)\end{array}$ & \begin{tabular}{|l|}
$0.00 \pm 0.00$ \\
$(0.71)$ \\
\end{tabular} & $\begin{array}{l}0.10 \pm 0.10 \\
(0.75)\end{array}$ & 0.04 & $\mathrm{NS}$ \\
\hline Ichneumonoidea & \begin{tabular}{|l|}
$4.90 \pm 0.68$ \\
$(2.19)^{\mathrm{a}}$ \\
\end{tabular} & $\begin{array}{l}1.60 \pm 0.63 \\
(1.21)^{\mathrm{b}} \\
\end{array}$ & $\begin{array}{l}0.85 \pm 0.35 \\
(1.05)^{\mathrm{b}}\end{array}$ & $\begin{array}{l}0.00 \pm 0.00 \\
(0.71)^{\mathrm{c}}\end{array}$ & \begin{tabular}{|l|}
$0.00 \pm 0.00$ \\
$(0.71)^{\mathrm{c}}$ \\
\end{tabular} & $\begin{array}{l}0.00 \pm 0.00 \\
(0.71)^{\mathrm{c}}\end{array}$ & 0.16 & 0.32 \\
\hline Platygasteroidae & $\begin{array}{l}1.05 \pm 0.26 \\
(1.15)^{c}\end{array}$ & $\begin{array}{l}11.55 \pm 2.35 \\
(3.11)^{\mathrm{a}}\end{array}$ & $\begin{array}{l}4.85 \pm 2.16 \\
(1.78)^{\mathrm{b}}\end{array}$ & $\begin{array}{l}0.35 \pm 0.10 \\
(0.88)^{\mathrm{c}}\end{array}$ & $\begin{array}{l}0.00 \pm 0.00 \\
(0.71)^{c}\end{array}$ & $\begin{array}{l}0.00 \pm 0.00 \\
(0.71)^{\mathrm{c}}\end{array}$ & 0.29 & 0.59 \\
\hline Proctotrupoidea & $\begin{array}{l}0.00 \pm 0.00 \\
(0.71)^{\mathrm{b}}\end{array}$ & $\begin{array}{l}0.40 \pm 0.18 \\
(0.89)^{\mathrm{a}}\end{array}$ & $\begin{array}{l}0.00 \pm 0.00 \\
(0.71)^{\mathrm{b}}\end{array}$ & $\begin{array}{l}0.00 \pm 0.00 \\
(0.71)^{\mathrm{b}}\end{array}$ & $\begin{array}{l}0.00 \pm 0.00 \\
(0.71)^{\mathrm{b}}\end{array}$ & $\begin{array}{l}0.00 \pm 0.00 \\
(0.71)^{\mathrm{b}}\end{array}$ & 0.04 & 0.09 \\
\hline
\end{tabular}

Sweep net - 400 min.; YPT-1- yellow pan trap (ground level) 351 trap days; YPT-2- yellow pan trap (erected) 199 trap days; Malaise trap - 20 trap days; suction trap - $200 \mathrm{~min}$ and light trap $3600 \mathrm{~min}$.

NS- Non Significant 
(ground level) can be regarded as the best method with a mean collection of $4.85 \pm 1.37$ diaproids per day. Evanoids were caught only in sweep netting and light traps with a mean of $0.25 \pm 0.20$ and $0.10 \pm 0.10$ evanoids per day, respectively. For the collection of Ichneumonidea, sweep net was found to be statistically superior method over other methods with a mean of $4.90 \pm 0.68$ ichneumonoids per day. Yellow pan traps both at ground level and erected were also found to trap ichneumonoids and are on par with each other. Among the super families collected, Platygasteroidae outnumbered with $11.55 \pm 2.35$ individuals per day under the sampling method, yellow pan trap at ground level followed by yellow pan trap erected at canopy levels (4.85 \pm 2.16 platygastroids per day). Sweep netting captured $1.05 \pm 0.26$ platygastroids whereas the Malaise trap caught $0.35 \pm 0.10$ platygastroids per day. For the collection of Proctotrupoidea, yellow pan trap ground level was found to be the best method which recorded a mean of $0.40 \pm 0.18$ individuals per day. No proctotrupoids were collected using the the other five methods that were employed in the present study.

\section{Evaluation of effficiencies of different parasitoid collect- ing devices}

The study revealed yellow pan trap kept at ground level as the most effective method with 27.2 parasitoids/ day i.e., 53 per cent of total parasitoids that were collected in the present study. The reason for the attraction of certain groups to yellow colour is not clear, although Kirk (1984) suggested that parasitoids would show a positive response to yellow. Moreover, for many hymenopterans, the attraction may be more to the water in the trap that to yellow itself. It is also reported that the species that are rarely swept can often be collected by yellow pan trap (Kennedy et al., 1961; Hollingworth et al., 1970). The results obtained in the present study is in accordance with the results of Campbell and Hanula (2007) who assessed the effectiveness of malaise trap to collect hymenopteran pollinators against yellow coloured pan traps and concluded that yellow pan traps as the most effective. It is also reported that the yellow pan trap was more efficient than malaise trap or any other flight intercept traps in capturing non formicid-hymenopterans (Wells and Decker, 2006). Daniel and Ramaraju, 2017 found that yellow pan trap kept at ground level trapped a mean 2.45 pteromalids per day. For the pteromalid, Trichomalopsis thekkadiensis, yellow pan trap kept at ground level was the best method of trapping, which recorded a mean of 0.35 pteromalids per day which was found to be statistically superior than the efficiencies of all other collecting devices which they have employed.
The second best gadget is the sweep net, 24 per cent of total parasitoids collection in the study was contributed by sweep net method (Figure 1). This is in conformity with the results obtained by Noyes (1989) who studied parasitic hymenoptera capture rates of different traps claiming sweep net as one of the effective collecting device. Sweep net is generally considered as the simplest and effective method to collect insects especially the parasitic hymenopterans (Narendran, 2001). Daniel and Ramaraju, 2017 concluded that Sweep net sampling is found to be the most effective method of sampling Brachymeria euploeae and Antrocephalus nasutus (Chalcididae: Hymenoptera) than yellow pan trap kept at ground level and yellow pan trap erected. Further, they have found out that sweep net is statistically superior in trapping these species with a mean number of $0.25 \mathrm{~B}$. euploea per day and 4.70 A. nasutus per day.

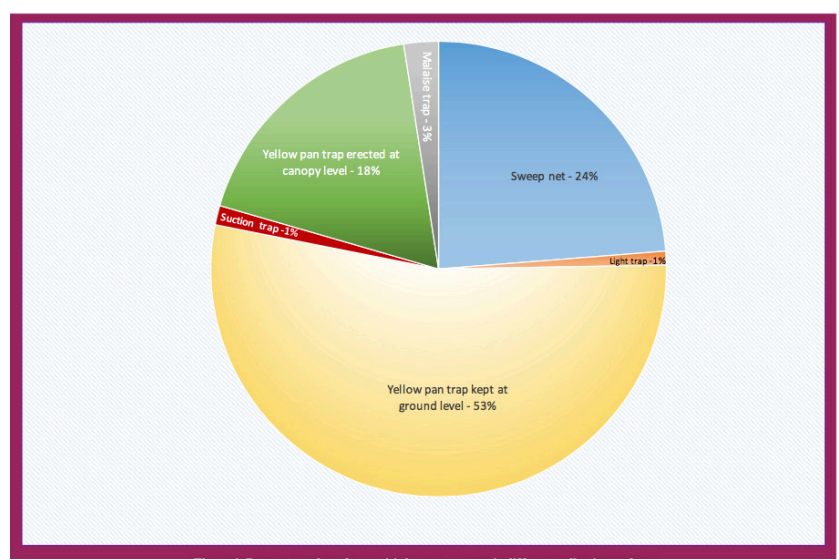

Fig. 1. Per cent catches of parasitic hymenopterans different collecting gadgets.

The main advantage of sweeping over pan trapping is that it is possible to sample a larger area, whereas yellow pan trap has a distinct advantage that the effort put by the collector is comparatively less. Moreover, in wet conditions (Rainy days) sweeping may be much difficult. It is observed that bigger parasitic groups viz., ichneumonoids, vespoids and bigger chalcidoids were caught more in numbers $(98,4$ and 79 , respectively) by sweeping. One possible explanation for the trapping of more number of bigger parasitic group using sweep net is that the coarse mesh of the sweep net allows smaller parasitoids to pass through it or escape before they enter the collecting head. This may be the reason why yellow pan trap kept at ground level stood first in collecting more number of smaller parasitoid groups such as ceraphronoids (72), smaller chalcidoids (101), platygastroids (231), diaproids (97) and proctotrupoids (8) (Figure 2). 


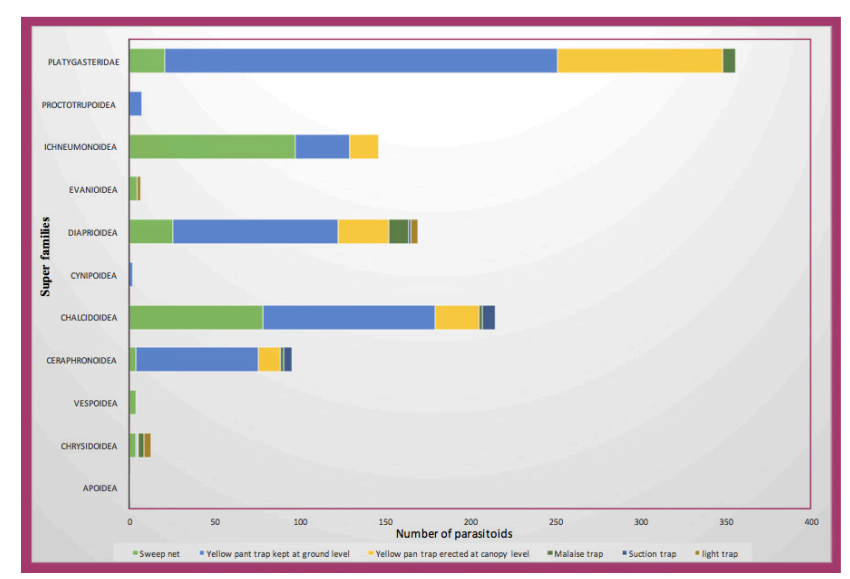

Fig. 2. Parasitic hymenopteran super families trapped in different collecting gadgets.

The next best sampling method is yellow pan trap erected at canopy level which contributed 18 per cent of total parasitoid collections. In the present study, yellow pan trap was also erected at canopy levels considering the fact that the yellow pan trap kept at ground level may get disturbed by the movement of birds in rice ecosystem and by man or even by wind. Moreover, we thought that if yellow pan traps are installed in the standing crop of rice at its canopy level, more number of parasitoids may get attracted towards it right from the foliage than to those kept at ground level. But it was found wrong through this study where, minimum number of parasitoids (lesser than yellow pan trap kept at ground level) got trapped in yellow pan trap kept at plant canopy. However, certain strong fliers in the family Braconidae were found to be trapped in yellow pan trap erected at canopy levels.

The other three traps viz., malaise trap, suction trap and light trap were found to collect less number $(<3 \%)$ of parasitoids. But this is in contrast with the results of Shweta and Rajmohana (2016) who studied parasitic hymenoptera capture rates of sweep net, malaise trap and yellow pan traps claiming malaise trap as the most efficient collection gadget over sweep net and yellow pan trap. The studies of Devigne and De-Biseau (2014) on the effectiveness of traps to capture insects from six different locations also concluded that malaise trap was the most effective in capturing various orders of insects. Effectiveness of traps was studied in detail by Darling and Packer in 1988 and suggested malaise trap with different mesh types to be the most effective in capturing hymenopterans. Usually taxonomists employ malaise trap for the collection of parasitoids. Though malaise trap is one of the the best option, for parasitoid collection in forest areas (Noyes, 1989; Shweta and Rajmohana, 2016), its installation in the standing rice crop is difficult and the results of current study also prove that.
The varying success rates of the different methods may have been influenced by vegetation as well as by differences in abundance, or perhaps the behavior of the parasitoids at the sites. When detailed information on the behavior of target group is known, it would be possible to employ a single most suitable method of capture (Spafford and Lortie, 2013), effectively saving time and effort. It is difficult to point out the exact reason for the preference of the parasitoids to get caught by each trap. Additional studies on the natural history and bio ecological aspects of the species could reveal more on the possible reasons for such results as rightly pointed out by Shweta and Rajmohana (2016). Such studies should be carried out for different groups of parasitoids over a longer period of time so as to re confirm the results. It is a well known fact that each group of insects requires its own specialized technique and apparatus for trapping. If the wrong technique is used, the catch may be very poor and the results must be misleading, apart from tiresome and time taking efforts of the workers.

\section{CONCLUSION}

Based on the present study it is suggested that surveys of parasitoids in rice ecosystems should be conducted using wide variety of methods as possible, because every method is undoubtedly having some advantage over other. Hence, to get a diverse collection of parasitoids, the use of as many collecting devices as possible is recommended.

\section{ACKNOWLEDGMENTS}

Thanks are due to Ministry of Minority Affairs, Government of India for the financial grants through Maulana Azad National Fellowship.

\section{REFERENCES}

Campbell JW, Hanula JL. 2007. Efficiency of malaise traps and colored pan traps for collecting flower visiting insects from three forested ecosystems. $J$ Insect Conserv. 11: 399-408. https://doi.org/10.1007/s10841006-9055-4

Daniel JA, Ramaraju K. 2017. A study of three methods of sampling chalcididae and Pteromalidae In Major Rice Ecosystems of Tamil Nadu. J Exp Zool India 20(2): 1037-1041.

Darling DC, Packer L. 1988. Effectiveness of Malaise traps in collecting Hymenoptera: the influence of trap design, mesh size and location. Can Entomol. 120: 787-796. https://doi.org/10.4039/Ent120787-8 
Devigne C, Biseau J. 2014. Urban ecology: Comparison of the effectiveness of five traps commonly used to study the biodiversity of flying insects. Biodivers J. 5: 165-174.

Fritz LL, Heinrichs EA, Machado V, Andreis TF, Pandolfo M, Salles SM, Oliveira, JV. 2011. Diversity and abundance of arthropods in subtropical rice growing areas in the Brazilian south. Biodivers Conserv. 20(10): 2211-2224. https://doi.org/10.1007/s10531-011-0083-3

Heckman CW. 1979. Rice field ecology in North East Thailand. Monogr Biol. 34: 228.

Heong KL, Aquino GB, Barrion AT. 1991. Arthropod community structures of rice ecosystems in the Philippines. Bull. Entomol Res. 81(4): 407-416. https://doi. org/10.1017/S0007485300031977

Hollingworth JP, Hartstack AWT, Lingren PD. 1970. The spectral response of Campoletis perdistinctus. J Econ Entomol. 63: 1758-1761. https://doi.org/10.1093/ jee/63.6.1758

Jervis DI, Padoch C, Cooper HD. 2007. Managing biodiversity in agricultural ecosystems. Columbia University Press. pp. 34-76. https://doi.org/10.7312/jarv13648

Jonathan JK. 2006. Ichneumonologia Indica, Hymenoptera: Ichneumonidae. Zool Suru India, Kolkata. 160p.

Kennedy JS, Booth C, Kershaw WJS. 1961. Host finding by aphids in the field by visual attraction. Ann Appl Biol. 49: 1-24. https://doi.org/10.1111/j.1744-7348.1961. tb03587.x

Kirk WD. 1984. Ecologically selective coloured traps. Ecol Entomol. 9: 35-41. https://doi.org/10.1111/j.1365-2311.19 84.tb00696.x

La Salle J, Gauld ID. 1993. Hymenoptera: Their diversity and their impact on the diversity of other organisms. In: Lasalle J and Gauld, ID. (Eds.). Hymenoptera and biodiversity. Wallingford, UK: CAB International. pp. 1-26.
Narendran TC. 1994. Torymidae and Eurytomidae of Indian subcontinent (Hymenoptera: Chalcidoidea). Zoological monograph. Calicut. 493p.

Narendran TC. 2001. Parasitic Hymenoptera and biological control: Palani Paramount Publications, Palani, India. pp. 6-190. https://doi.org/10.1007/978-1-4615-1377-3_1

Noyes JS. 1989. A study of five methods of sampling Hymenoptera (Insecta) in a tropical rainforest, with special reference to the Parasitica. J Nat Hist. 23: 285-298. https://doi.org/10.1080/00222938900770181

Noyes JS. 2017. Universal Chalcidoidea Database. World Wide Web electronic publication. Retreived from: hhtp:// www.nhm.ac.uk/chalcidoids.

Rajmohana K. 2006. Studies on Proctotrupoidea and Platygastroidea (Hymenoptera: Insecta) of Kerala. Memoirs Zool Surv India. 2(1): 1-53.

Shweta M, Rajmohana K. 2016. A comparison of efficiencies of sweep net, yellow pan trap and malaise trap in sampling Platygastridae (Hymenoptera: Insecta). J Exp Zool India. 19: 393-396.

Spafford RD, Lortie CJ. 2013. Sweeping beauty: is grassland arthropod community composition effectively estimated by seep netting? Ecol Evol. 3: 3347-3358. https://doi.org/10.1002/ece3.688

Sureshan PM. 2008. Pteromalinae (Pteromalidae: Chalcidoidea: Hymenoptera) of Indian Subcontinent. Rec zool Surv India 205: 1-170.

Wells W, Decker T. 2006. A comparison of three types of insect traps for collecting non-Formicidae Hymenoptera on the Island of Dominica. Southwest. Entomology 31: 59-68. 